\title{
Proses Pengolahan Air pada Alat Filtrasi dengan Variasi Laju Alir, Perbandingan Volume antara Pasir dan Karbon Aktif di PLTG Borang
}

\author{
Dadang S Manaf ${ }^{* 1}$, Erwana Dewi ${ }^{2}$, Jaksen $^{3}$ \\ 1,2,3 Program Studi Teknologi Kimia Industri, Jurusan Teknik Kimia \\ Politeknik Negeri Sriwijaya, Indonesia \\ J1. Srijaya Negara Bukit Besar Palembang \\ Email : ${ }^{1}$ dadangmanaf17@gmail.com
}

\begin{abstract}
Abstrak
PT PLN (Persero) PLTG Borang merupakan salah satu industri yang mendapatkanair bersih dengan melakukan pengolahan pada unit WTP. Unit WTP di PLTG Borang mengalami permasalahan di beberapa alat seperti misalnya pada alat Filtrasi. Permasalahan yang ditemui untuk dijadikan studi kasus yaitu alat Filtrasi terutama pada laju alir dan ketebalan kolom belum optimal sehingga tidak menghasilkan air bersih yang sesuai standar. Studi kasus ini dilakukan pada bulan Maret hingga Juli 2021. Data-data yang dijadikan sumber yaitu data sekunder berupa data kondisi operasi dan hasil uji kualitas mutu air setelah pengolahan pada alat filter. Cara yang dilakukan yaitu membuat dua kolom dengan ketinggian berbeda yaitu $1000 \mathrm{~mm}$ dan 1200mm dengan perbandingan isian berupa pasir dan karbon aktif. Dari ketinggian dua kolom tersebut masing-masing di variasikan menjadi tiga perbandingan yaitu 2:1, 1:1 dan 1:2 antara pasir dan karbon aktif. Sedangkan parameter uji kualitas yang diperlukan yaitu nilai $\mathrm{pH}$, turbiditas atau kekeruhan, jumlah padatan terlarut, total padatan tersuspensi, nilai kadar DO, serta COD dan BOD..Dari penelitian yang dilakukan di dapatakan laju alir optimal yaitu $1 \mathrm{~L} /$ menit dengan ketinggian isian kolom $1200 \mathrm{~mm}$ pada perbandingan 1:2 antara pasir dan karbon aktif.
\end{abstract}

Kata kunci: filtrasi, karbon aktif, kekeruhan, sungai, TDS, TSS, water treatment plant.

\section{Water Treatment Process in Filtration Equipment with Variation of Flow Rate, Volume Comparison between Sand and Activated Carbon in PLTG Borang}

\begin{abstract}
PT PLN (Persero) PLTG Borang is one of the industries that get clean water by processing the WTP unit. The WTP unit at the Borang PLTG experienced problems in several tools such as the Filtration tool. The problem encountered to be used as a case study is that the Filtration tool, especially at the flow rate and column thickness, has not been optimal so that it does not produce clean water according to standards. This case study was conducted from March to July 2021. The data used as sources are secondary data in the form of operating condition data and the results of water quality tests after processing on the filter. The way to do this is to make two columns with different heights, namely $1000 \mathrm{~mm}$ and $1200 \mathrm{~mm}$ with a ratio of filling in the form of sand and activated carbon. From the height of the two columns, each was varied into three ratios, namely 2:1, 1:1 and $1: 2$ between sand and activated carbon. Meanwhile, the required quality test parameters are $\mathrm{pH}$ value, turbidity or turbidity, amount of dissolved solids, total suspended solids, DO level values, as well as COD and BOD. 1200 $\mathrm{mm}$ at $1: 2$ ratio between sand and activated carbon.
\end{abstract}

Keywords: activated carbon, filtration, river, turbidity, TDS, TSS, water treatment plant.

\section{PENDAHULUAN}

PLTG Borang merupakan perusahaan yang bergerak di bidang penyediaan energi listrik. Perusahaan ini dibangun oleh PT Sewatama dan PT Wijaya Karya pada tahun 2003 yang berlokasi di Desa Merah Mata, Kabupaten Banyuasin. Pembangunan berlangsung selama satu tahun, sehingga pada tahun 2004 PLTG sudah mulai beroperasi. Namun setelah 6 tahun beroperasi muncul suatu masalah berupa reverse power sehingga pada tahun 2011 PT Wijaya Karya bersama dengan PT PLN membangun unit baru berkapasitas 2 x $30 \mathrm{MW}$.

Unit water treatment plant di PT PLN (Persero) PLTG Borang mengalami permasalahan di beberapa alat, sehingga produksi akhir dalam pengolahan air tidak memenuhi standar. Salah satu permasalahannya yaitu pada 
tangki filtrasi yang dimana tempat terjadinya proses penyaringan. Hasil pengolahan air pada tangki ini belum memenuhi standar yang berlaku. Parameter kualitas yang tidak memenuhi standar tersebut antara lain : kekeruhan, $\mathrm{pH}$, jumlah padatan terlarut, jumlah padatan tersuspensi, serta DO, BOD dan COD.

Filtrasi adalah proses pemisahan padatan dengan larutan, dimana larutan tersebut dilewatkan melalui suatu media berpori atau materi berpori lainnya untuk menyisihkan partikel tersuspensi yang sangat halus sebanyak mungkin. Proses ini dilakukan pada instalasi pengolahan air minum untuk menyaring air yang telah dikoagulasi dan diendapkan untuk menghasilkan air minum dengan kualitas yang baik [1].

Filtrasi dapat digunakan dengan menggunakan beberapa jenis filter, antara lain: saringan pasir lambat, saringan pasir cepat, bahkan dengan menggunakan teknologi membran. Pada pengolahan air minum umumnya dipergunakansaringan pasir cepat, karena filter jenis ini memiliki debit pengolahan yang cukup besar, penggunaan lahan yang tidak terlalu besar, biaya operasi dan pemeliharaan yang cukup rendah dan tentunya kemudahan dalam pengoperasian dan pemeliharaan [2]. Alat filtrasi ini menggunakan carbon aktif sebagai penyaring.

Pada umumnya bahan baku karbon yang terdapat pada binatang, tanaman atau mineral dapat dijadikan arang. Sebagai contoh dari binatang (daging dan tulang), tanaman (kayu ringan, kayu berat, sekam padi, kulit kacang), serta mineral (petroleum residu, carbon black). Akan tetapi secara ekonomi, tulang, kayu, umumnya digunakan untuk penyerap warna, sedang tempurung kelapa, batu bara dan residu petroleum untuk penyerap gas. [3]. Karbon aktif secara komersial disebut "Eponite" pada tahun 1909 karbon aktif merupakan pendahulu dalam pengembangan pembuatan karbon aktif secara modern dengan menggunakan chlor pada pemanasan tinggi untuk aktivitasnya [4].

Sifat adsorpsi atau kemampuan penyerapan yang dimiliki oleh karbon aktif sendiri dipengaruhi oleh beberapa hal antara lain [5].

1.Sifat fisika karbon aktif Sifat fisika karbon aktif dipengaruhi oleh sedikit atau banyaknya jumlah pori pori yang ada di dalam karbon aktif itu sendiri yang bisa dimasuki oleh bahan adsorbat yang ada di dalam karbon aktif. 2.Sifat kimia karbon aktif Karbon aktif mempunyai sifat kimia ketika proses aktivasi berlangsung. Gugus aktif yang dimiliki karbon aktif akan berinteraksi dengan molekul organik secara kimiawi. Proses adsorpsi terjadi karena adanya gaya Van Der Waals pada permukaan karbon aktif dan adsorbat. 3.Jenis adsorbat Adsorbat yang bersifat tidak tarik menarik atau biasa disebut nonpolar akan lebih mudah berinteraksi dengan gugus aktif pada karbon aktif. Sehingga molekul organik yang memiliki nilai kelarutan kecil pada air akan berikatan cukup kuat dengan karbon aktif. 4.Suhu Karbon aktif akan memiliki daya serap yang jauh lebih besar apabila suhu nya rendah dibandingkan dengan suhu yang tinggi, karena kelarutan molekul adsorbat lebih kecil sehingga lebih banyak yang bisa teradsorpsi. 5.Waktu kontak Semakin lama waktu kontak antara adsorbat dengan karbon aktif maka semakin banyak pula adsorbat yang bisa terserap ke dalam permukaan karbon aktif. 6.Luas permukaan karbon aktif Karbon aktif akan memiliki daya serap yang jauh lebih besar apabila karbon aktif memiliki permukaan yang luas dibandingkan dengan karbon aktif yang memiliki permukaan yang sempit. 7.Konsentrasi adsorbat dan ukuran partikel adsorbat Karbon aktif akan menjadi cepat jenuh apabila konsentrasi dan partikel adsorbat semakin besar.

Pasir silika atau pasir kuarsa telah lama dikenal sebagai salah satu media filter air yang sangat baik. Kualitas pasir juga sangat dipengaruhi oleh keadaan musim di sekitar daerah pasir tersebut. 18 Kualitas pasir silika atau pasir kuarsa akan sangat buruk ketika memasuki musim kemarau dan memiliki kualitas yang baik ketika memasuki musim penghujan [6].

Proses adsorpsi akan terjadi karena adanya gaya tarik antar atom atau molekul pada permukaan padatan yang tidak seimbang. Dengan eksistensi gaya ini, padatan akan cenderung menarik molekul - molekul lain yang berkontak langsung dengan surface padatan, baik fasa gas atau fasa larutan ke dalam permukaannya. Akibatnya konsentrasi molekul pada permukaan menjadi lebih besar dari pada dalam fasa gas zat terlarut dalam larutan. Pada proses adsorpsi hubungan antara adsorben dengan adsorbat hanya akan terjadi pada permukaan adsorben [7].

Kondisi intake sangat berpengaruh dalam suplai air yang akan diolah. Untuk menjamin suplai air cukup, intake diletakkan di lokasi yang mudah dicapai dan direncanakan untuk mensuplai jumlah kuantitas air pada kualitas optimal yang memungkinkan [8]. Kemudian proses prasedimentasi. Proses ini terjadi pada bak pengendapan awal. Air dari unit intake dialirkan menuju bak prasedimentasi untuk membuang pasir, lempung, jenis partikel non koloid lainnya secara gravitasi.

Partikel besar telah mengendap pada bak prasedimentasi. Setelah itu partikel kecil diolah pada alat clarifier tank. Partikel-partikel kecil digumpalkan sehingga membentuk flok yang lebih besar. Namun masih terdapat partikel seperti dissolved solid sehingga perlu diolah lagi pada bagian filtrasi.

Filtrasi dapat digunakan dengan menggunakan beberapa jenis filter, antara lain: saringan pasir lambat, saringan pasir cepat, bahkan dengan menggunakan teknologi membran. Pada pengolahan air bersih umumnya dipergunakansaringan pasir cepat, karena filter jenis ini memiliki debit pengolahan yang cukup besar, penggunaan lahan yang tidak terlalu besar, biaya operasi dan pemeliharaan yang cukup rendah dan tentunya kemudahan dalam pengoperasian dan pemeliharaan [9]. 
Air bersih yaitu air yang aman (sehat) dan baik untuk diminum, tidak berwarna, tidak berbau, dengan rasa yang segar [10]. Air bersih di PLTG Borang digunakan untuk keperluan pencucian peralatan, domestik kantor dan pengisi hidran.

\section{METODE PENELITIAN}

\subsection{Waktu dan Tempat}

Studi Kasus Alat Clarifier Tank pada Unit Water Treatment Plant di PT PLN (Persero) PLTG Borang dilaksanakan pada bulan Maret - Juli 2021. Pengamatan dan Pengambilan data dilakukan di unit WTP bagian Filtrasi PLTG Borang pada April - Mei 2021. Adapun tahapan pelaksanaan studi kasus meliputi kegiatan lapangan, analisis data dan pelaporan.

\subsection{Prosedur Studi Kasus}

Studi kasus dimulai dengan mengumpulkan seluruh referensi berupa studi literatur sesuai dengan permasalahan. Perlakuan ditentukan berupa variabel proses terhadap kualitas air hasil pengolahan. Percobaan dilakukan terhadap alat dan mengumpulkan data pengamatan. Data pengamatan dilakukan analisis untuk mendapatkan simpulan berupa variabel proses yang optimal agar mendapatkan kualitas air setelah pengolahan yang terbaik.

\subsection{Sumber Data}

Sumber data diambil dari data historisis, observasi langsung dan studi pustaka. Dalam hal ini data yang digunakan adalah data hasil pengamatan, data penelitian yang telah dilakukan oleh industri dan literatur atau pustaka yang mendukung studi kasus ini.

\subsection{Variabel Proses dan Kualitas Air Hasil}

Variabel proses divariasikan yaitu laju alir 1, 2, 3,4 dan $5 \mathrm{~L} / \mathrm{s}$; ketinggian kolom $1000 \mathrm{~mm}$ dan $1200 \mathrm{~mm}$; dengan masing-masing perbandingan 2:1, 1:1, dan 1:2. Kualitas air yang akan diukur yaitu pH, turbiditas, jumlah padatan terlarut, dan total padatan tersuspensi.

\subsection{Variabel Proses dan Kualitas Air Hasil}

Analisis yang digunakan pada studi kasus ini yaitu analisis deskriptif dan interpretasi. Analisis deskritif yakni menghubung-hubungkan antara data yang satu dengan data yang lainnya, kemudian menarik benang merah dari data tersebut sehingga diperoleh gambaran secara utuh studi kasus yang dilakukan secara mendalam. Sedangkan analisis interpretasi yaitu dengan menyajikan data variabel proses dan hasil kualitas air ke dalam bentuk diagram atau grafik, kemudian menentukan hubungan serta kondisi optimum yang dicapai.

\section{HASIL DAN PEMBAHASAN}

Ada 4 kriteria kualitas air hasil proses yang dianalisis yaitu $\mathrm{pH}$, kekeruhan, jumlah padatan terlarut dan jumlah padatan tersuspensi. Derajat keasaman atau $\mathrm{pH}$ memiliki rentang standar 7 - 9 (SNI, 2012), sedangkan kekeruhan, TDS dan TSS memiliki nilai standar maksimum. Hal ini berarti kriteria baku mutu air setelah melewati Filtrasi yang meliputi kekeruhan, TDS dan TSS diharapkan mengalami penurunan, sedangkan $\mathrm{pH}$ harus berada pada rentang nilai standar.

\subsection{Pengaruh laju alir dan perbandingan kolom terhadap $\mathrm{pH}$}

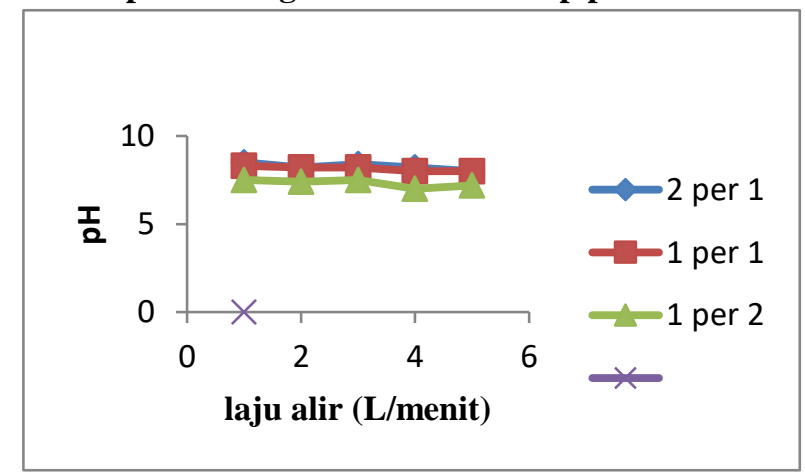

Gambar 1. Grafik Pengaruh Ketinggian Kolom (1000 mm) terhadap pH dengan Variasi Laju Alir dan Perbandingan pasir dengan Karbon Aktif. 


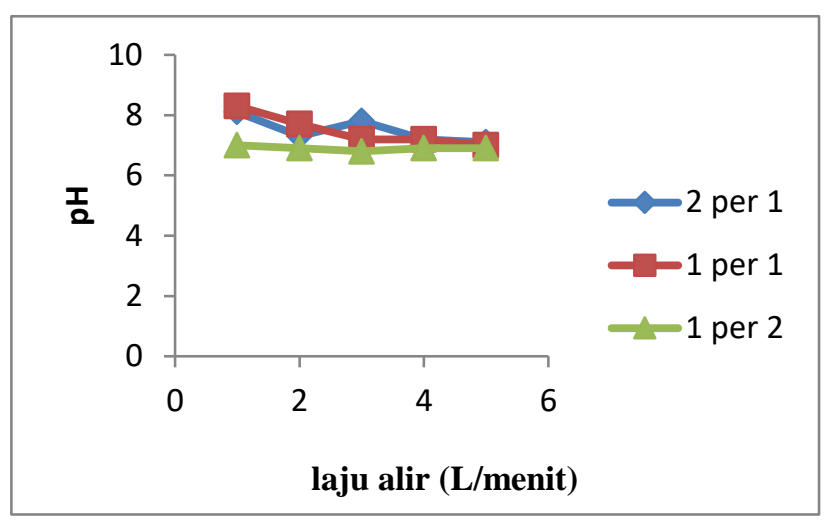

Gambar 2. Grafik Pengaruh Ketinggian Kolom (1200 mm) terhadap pH dengan Variasi Laju Alir dan Perbandingan Pasir dengan Karbon Aktif.

Gambar 1 dan 2 menunjukkan bahwa ketinggian dan perbandingan ketinggian pasir dengan karbon aktif menyebabkan perubahan $\mathrm{pH}$ atau tingkat keasaman. Hal ini disebabkan karena perbedaan ketinggian kolom antara pasir dan karbon aktif. Ada tiga perbandingan dalam percobaan ini, yaitu 1 berbanding 2 , 1 berbanding 1 dan 2 berbanding s1 antara pasir dan karborbon aktif. Setelah air keluar dari proses koagolan air di alirkan ke unit filtrasi untuk diolah ketahap terakhir. Pada perbandingan pertama, tingkat keasaman semakin tinggi laju alir maka tingkat keasaman air semakin tinggi, begitu juga pada perbandingan kedua dan ketiga. Hal ini dipengaruhi oleh factor ketebalan antara pasir dan karbon aktif tadi. Pada gambar 4.1 menunjukan ketebalan kolom 1000 mm, bisa kita lihat kandungan tingkat keasaman masih menunjukan basah. Grafik menunjukan tingkat keasaman rata-rata di atas 8, sedangkan pada gambar 4.2 bisa diketahui dengan ketinggian kolom $1200 \mathrm{~mm}$ dengan perbandingan 1 berbanding 2 antara pasir dan karbon aktif tingkat keasaman optimal yaitu antara 6-7,5. Hal ini telah menunjukan bahwa dengan perbandingan tersebut mampu menghasilkan baku mutu tingkat keasaman yang baik.

\subsection{Pengaruh laju alir dan perbandingan kolom terhadap turbiditas}

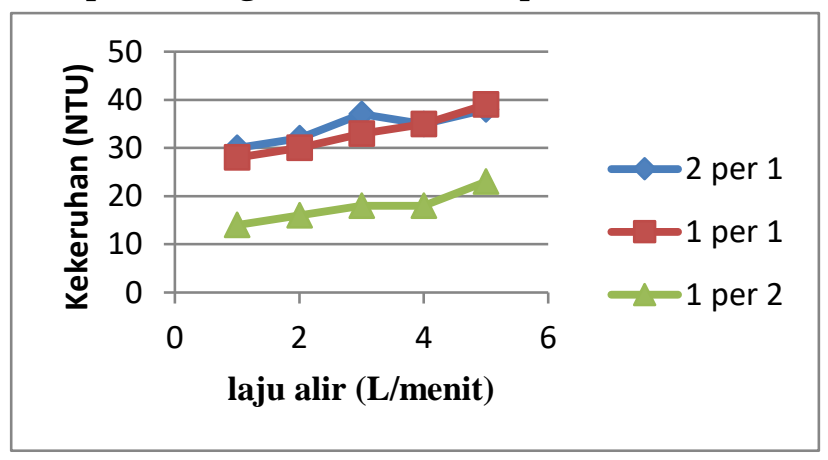

Gambar 3. Grafik Pengaruh Ketinggian Kolom (1000 mm) terhadap Penurunan Kekeruhan dengan Variasi Laju Alir dan Perbandingan Pasir dengan Karbon Aktif.

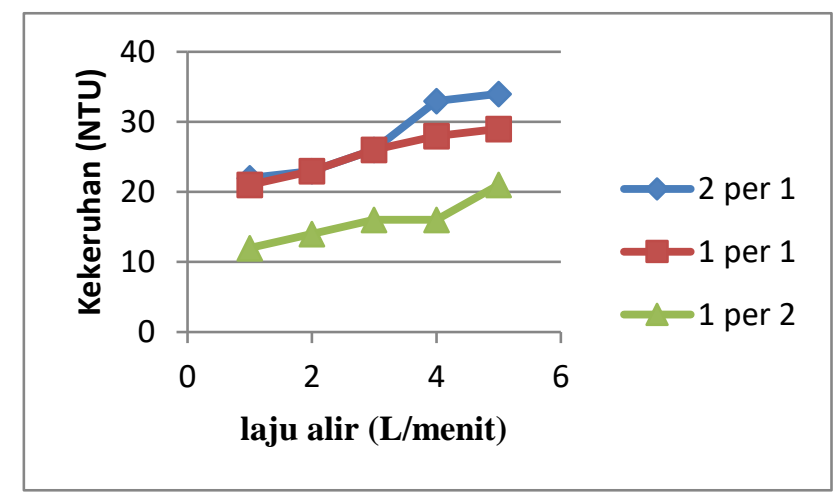

Gambar 4. Grafik Pengaruh Ketinggian Kolom (1200 mm) terhadap \% Penurunan Kekeruhan dengan Variasi Laju Alir dan Perbandingan Pasir dengan Karbon Aktif 
Pada gambar 3 dan 4 terlihat bahwa ketinggian kolom yang optimum yaitu $1200 \mathrm{~mm}$ dengan perbandingan 1 berbanding 2. Penggunaan karbon aktif yang semakin banyak akan menghasilkan penurunan kekeruhan yang besar sehingga air akan menjadi lebih jernih. Namun jika pasir terlalu tinggi, dalam hal ini 2 berbanding 1, maka akan mengurangi penurunan kekeruhan. Hal ini disebabkan karena pasir hanya menahan kotoran yang kasar saja, sehingga beberapa partikel tidak mampu diserap. Laju alir yang rendah menghasilkan penurunan kekeruhan yang tinggi sehingga air akan semakin jernih. Hal ini terjadi karena pada laju alir yang besar kemungkinan lolosnya partikel ke zona jernih akan semakin besar pula dan sebaliknya. Sementara itu laju alir dengan kecepatan 2 L/detik dengan ketinggian kolom $1200 \mathrm{~mm}$ dengan perbandingan 2 berbanding 1 merupakan yang optimum dibandingkan dengan ketebalan kolom yang lain.

\subsection{Pengaruh laju alir dan ketebalan kolom terhadap TDS}

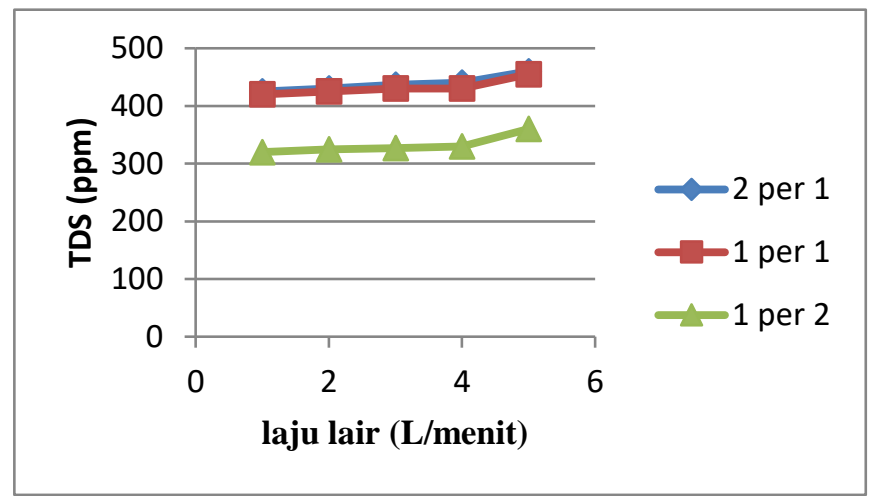

Gambar 5. Grafik Pengaruh Ketinggian Kolom (1000 mm) terhadap \% Penurunan TDS dengan Variasi perbandingan Pasir dengan Karbon Aktif

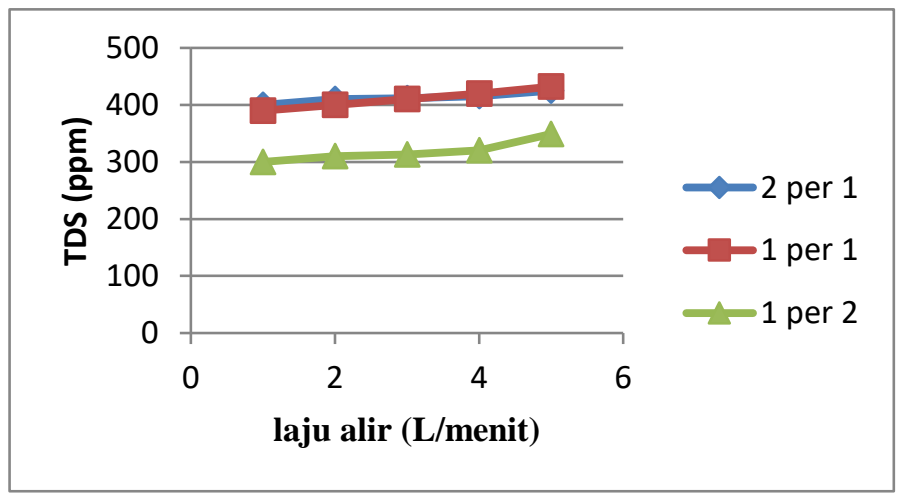

Gambar 6. Grafik Pengaruh Ketinggian Kolom (1200 mm) terhadap \% Penurunan TDS dengan Variasi Laju Alir dan Perbandingan Pasir dan Karbon Aktif

Gambar 5 di atas menunjukkan bahwa ketinggian kolom dan perbandingan pasir dengan karbon aktif telah berhasil menurunkan jumlah padatan terlarut (TDS) yang ada di dalam air. Laju alir yang paling optimum adalah $1 \mathrm{~L} /$ detik dengan perbandingan 1 berbanding 2 . Dengan perbandingan 1 berbanding 2 jumlah menghasilkan penurunan nilai TDS yang tinggi, namun hal yang perlu dipertimbangkan adalah jumlah koagulan yang digunakan. Laju alir cenderung lebih baik jika menggunakan laju alir $1 \mathrm{~L} / \mathrm{s}$. Hal ini disebabkan jika laju alir tinggi, hal yang terjadi yaitu kemungkinan lolosnya flok ke zona jernih akan semakin besar.

Gambar 4.6 pada dasarnya sama dengan gambar 4.5, dimana ketinggian kolom $1200 \mathrm{~mm}$ dengan perbandingan 1 berbanding 2 yang optimum. Dengan ketinggian dan perbandingan itu akan menghasilkan penurunan TDS yang besar sehingga air akan menjadi lebih jernih. Kecepetan pengadukan $1 \mathrm{~L} /$ detik menghasilkan penurunan TDS yang lebih baik daripada kecepatan pengadukan yang lain. Jika dilihat dari dua grafik penurunan TDS ini, yang paling optimum adalah ketinggian kolom $1200 \mathrm{~mm}$ dengan perbandingan 1 perbanding 2. 


\subsection{Pengaruh laju alir dan ketebalan kolom terhadap TSS}

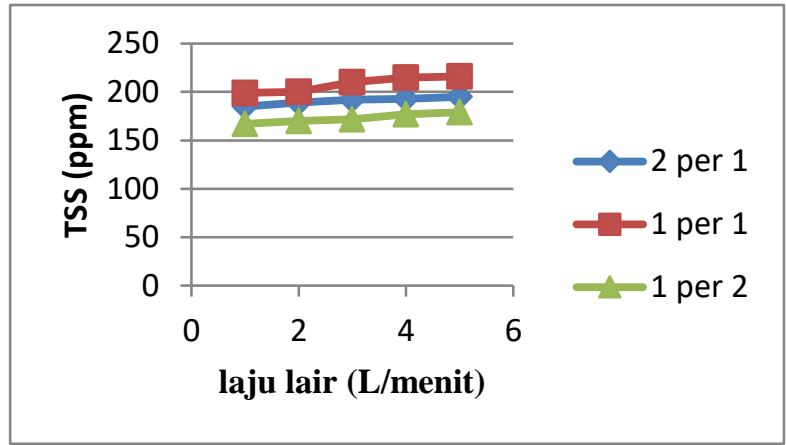

Gambar 7. Grafik Pengaruh Ketinggian Kolom (1000 mm) terhadap \% Penurunan TSS dengan Variasi Laju Alir dan Perbandingan Pasir dengan Karbon Aktif

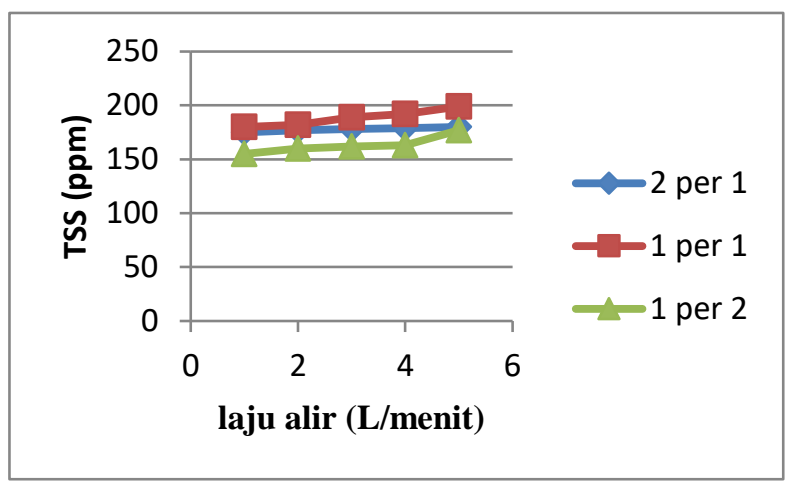

Gambar 8. Grafik Pengaruh Ketinggian Kolom (1200 mm) terhadap \% Penurunan TSS dengan Variasi Laju Alir dan Perbandingan Pasir dengan Karbon Aktif.

Pada gambar 4.7 dan 4.8 terlihat bahwa Ketinggian Kolom $1200 \mathrm{~mm}$ yang optimum yaitu dengan perbandingan 1 berbanding 2. Penggunaan karbon aktif yang semakin banyak akan menghasilkan penurunan TSS yang besar sehingga air akan menjadi lebih jernih. Jika karbon aktif lebih rendah maka TSS akan semakin kecil, dalam hal ini laju alir $1 \mathrm{~L} / m e n i t$ maka juga tetap menghasilkan air olahan yang baik, namun perlu dipertimbangkan faktor ketersediaan karbon aktif. Laju alir yang rendah menghasilkan penurunan TSS yang tinggi sehingga air akan semakin jernih. Hal ini terjadi karena pada laju alir yang besar kemungkinan lolosnya flok ke zona jernih akan semakin besar pula dan sebaliknya. Sementara itu perbandingan 1 berbanding 2 merupakan yang optimum dibandingkan dengan perbandingan 2 berbanding 1 dan 1 berbanding 1 .

\section{KESIMPULAN}

Kondisi operasi yang optimum dari alat Filtrasi dalam mengolah air baku sehingga dihasilkan pH sesuai standar serta penurunan kekeruhan, TDS dan TSS yang besar yaitu : Ketinggian Kolom : 1200 mm,Perbandingan Pasir dan Karbon aktif : 1 berbanding 2 dan Laju alir 1 L/menit serta kualitas air yang didapatkan telah memenuhi standar air bersih.

\section{DAFTAR PUSTAKA}

[1] Saputri, Proses Pengolahan Air, Jakarta: Erlangga, 2011.

[2] Mentenogoro, "Proses Pengolahan Air Berdasarkan Jenis-Jenis Karbon Aktif," Universitas Riau, Pekanbaru, 2012.

[3] Agusta, "Sifat Adsorbsi Atau Kemampuan Penyerapan," Jurnal Kimia Sains dan Terapan, vol. 2, no. 1, pp. 14-15, 2012.

[4] S. R. S. A. Syahputra, "Rancang Bangun Alat Penjernih Air yang Tercemar Logam Berat Fe, Cu, Zn dalam Skala Laboratorium," Universitas Riau, Pekanbaru, 2015. 
[5] Anna, "Pengolahan Air Limbah Tekstil Melalui Proses Koagolasi Flokulasi dengan Menggunakan Lempung Sebagai Penyumbang Partikel Tersuspensi," Arena Tekstil, vol. 3, no. 2, p. 106, 2016.

[6] Arifiani, "Evaluasi Desain Instalasi Pengolahan air PDAM ibu Kota Kecamatan Prambanan KabupatenKlaten," Jurnal Presipitasi, vol. 3, no. 2, p. 79, 2007.

[7] Rina, "Pengaruh Adsorben Terhadap Zat Terlarut dalam Larutan," Jurnal Sains, vol. 2, no. 1, p. 14, 2015.

[8] Dandi, "Pengaruh Karbon Aktif Terhadap Penjernihan Air," Universitas Negeri Padang, Padang, 2011.

[9] Reza, "Pengaruh Jenis-Jenis Filter," Jurnal Utilitas, vol. 3, no. 2, p. 12, 2012.

[10] Rehan, "Sifat-Sifat Air Bersih," Jurnal Sains, vol. 3, no. 2, p. 22, 2015. 